\title{
Vehicle Emissions Tax: An Opportunity to Control Air Pollution
}

\author{
Ninik Puji Astuti ${ }^{1, *}$, Maryono Maryono ${ }^{2}$ \\ ${ }^{1}$ Magister Program of Environmental Science, School of Postgraduate Studies, Diponegoro University, Semarang - Indonesia \\ ${ }^{2}$ Department of Urban and Regional Planning, Diponegoro University, Semarang - Indonesia
}

\begin{abstract}
This paper discusses about the condition of air quality in Indonesia and the opportunity to control air pollution using vehicle emissions tax. It is described descriptively based on literature, legal regulations, and prior researches. Transportation grow rapidly due to population growth. It is because transportation is very important for mobility and supports economic. Motor vehicles as a mean of transportation are known to cause air pollution due to their emissions. Pollutants in emissions are risk factors for several diseases, including acute respiratory infections, bronchitis, and pneumonia. Air quality in Indonesia, namely "indeks kualitas udara (IKU)" is still in good condition. However, there are provinces that have "moderate" IKU value and even "very less". A variety of ways are being done to control air pollution from the transportation sector. Unfortunately, in Indonesia still has not touched the economic side. Environmental economic instruments need to be developed to address this. Basically, the regulations has provided the opportunity for the implementation, such as Law Number 32 Year 2009, Law Number 28 Year 2009, and Government Regulation Number 46 Year 2017. Therefore, the study of vehicle emission tax that internalizes economic losses due to air pollution for public health needs to be done. This kind of study is expected to be an input for policymakers on air pollution control.
\end{abstract}

Keywords: air; emission; pollution; tax; vehicle.

\section{Introduction}

The population in Indonesia in 2008 was 228.5 million and reached 261.9 million in 2017 with a growth rate of $1.34 \%$ per year [1]. The growing number of people with their various activities has a major impact on the transportation sector due to its importance for mobility and support for the economy. In 2011 the number of motor vehicles in Indonesia reached 85,601,351 units then increased to $136,667,740$ units in 2017. It was dominated by motorcycles $(81.56 \%)$, ie $111,470,878$ units [1][2]. The growth of motor vehicles in Indonesia in the period 2012-2016 reached $8.19 \%$ per year. Java has the fastest growth rate of $9.28 \%$ per year [3].

The number of vehicles correlated to the fuel consumption. It will increase as result of travel length, personal transportation mode, and traffic density [4].

The transportation system has an effect on the quality of the environment [5]. This is closely related to exhaust emissions generated by motor vehicles from burning fuel that can pollute the air.

Pollutants in vehicle emissions are a risk factor for several diseases, including acute respiratory infections, asthma, bronchitis, pneumonia, and eye irritation. In 2016 there were 568,146 cases of infants' pneumonia in Indonesia [1].
Various efforts to control air pollution from the environment has been done in Indonesia, but not yet followed from the economic side. Environmental economic instruments need to be developed to overcome this. It is a set of economic policies to encourage the central government, local government, or each person toward the preservation of environmental functions [6]. One way that can be taken to control air pollution and as an environmental economic instrument is by internalizing the economic losses due to air pollution for public health at the motor vehicle tax rates [7].

The application of such as this taxes is expected to encourage people to reduce vehicle usage/ownership and at least maintain the performance of their vehicles so that the emissions can meet the required quality standards. On the other hand, losses due to air pollution, such as health problems will be minimized.

In addition, vehicles emission tax is expected to support low carbon development where the target of reducing carbon emissions in Indonesia has been set by $26 \%$ in 2020 . In order to reduce carbon emissions, the energy and transportation sector has set a target for reducing emissions by $0.036 \mathrm{Gton}$ of $\mathrm{CO}_{2}$.

* Corresponding author: astutipuji.ninik@gmail.com 


\section{Literature Review}

\subsection{Vehichle Emissions and Public Health}

Vehicle emissions are a major source of air pollutants in urban areas. These emissions are carbon monoxide (CO), carbon dioxide $\left(\mathrm{CO}_{2}\right)$, nitrogen oxide $\left(\mathrm{NO}_{\mathrm{x}}\right)$, hydrocarbon $(\mathrm{HC})$, sulfur oxide $\left(\mathrm{SO}_{\mathrm{x}}\right)$, and particulates matter $(\mathrm{PM})$. Emissions occur in three conditions: hot emission, start emission, and evaporation emissions (at the time of refueling, shortly after the engine off, parking conditions). The amount of emissions is determined by the speed, lifespan, and maintenance of the vehicle [8].

$\mathrm{CO}$ causes poisoning due to the formation of carboxy hemoglobin $(\mathrm{HbCO})$ in the blood. It disrupts $\mathrm{Hb}$ bringing $\mathrm{O}_{2}$ to the whole body. The supply of $\mathrm{O}_{2}$ in the body will be decrease and causes shortness of breath, even death. HC causes respiratory disorders, laryngitis, and bronchitis. The exposure of $\mathrm{NO}_{\mathrm{x}}>0.05 \mathrm{ppm}$ causes acute respiratory disorders [9]. $\mathrm{PM}_{10}$ causes respiratory tract irritation, coughing, difficulty in breathing, decreasing lung function, exacerbating asthma, chronic bronchitis, even death [10]. The impact of death from air pollution in Indonesia reaches about 3\% of Gross Domestic Product in 2010 [11].

\subsection{Motor Vehichles Externalities}

Externality is a positive impact (benefits) as well as the negative impact (cost) of an action made by a particular party against other without any compensation for the beneficiaries and the losers. Environmental externality is the cost and benefits caused by the changing of the biology and physics environment. Pollution emitted by the transport and industrial sectors impacts people and the environment. As a form of externality, unfortunately fuel consumption and waste disposal has not been charged for its impact as an environmental cost [12].

There are five externalities of motor vehicles usage, ie accident, congestion, road damage, environmental damage, and dependence on fuel. The environmental damage are exhaust emissions, noise, landscape and urban changes, and the impacts on biodiversity and buildings. Emissions and noise can be valued [13].

\subsection{Economic Valuation}

Economic valuation is an analysis in the preparation of public policy intervention scenarios, such as the determination of appropriate pricing strategies in the use of fiscal policy mechanisms, such as Pigovian tax [14]. Economic valuation is done by calculating the total value of degradation to find out the costs that need to be paid to the parties affected by pollution and/or environmental damage. This fee is paid out so that the affected parties will recover or not experience worse conditions. There are several economic valuation methods to measure the changing of air quality and health effects such as prevention cost expenditure, replacement cost, human capital, cost effectiveness of analysis of prevention, and benefit transfer [15].

\subsection{Environmental Taxes}

Law Number 16 Year 2009 states that tax is a compulsory contribution of citizens to a coercive state without obtaining direct rewards. Taxes are utilized for state purposes for the welfare of the citizen. With regard to environmental taxes, polluters are free to dispose waste/pollutants, but they are required to pay taxes for each waste/pollutant. The application of environmental taxes becomes an incentive for polluters to find the best way to minimize the emissions/waste/pollutants.

Tax is an action to prevent the occurrence of negative externalities. The environmental tax instrument is used to correct the social costs arising from the negative externalities caused by environmental pollution in which polluters have to pay due to their environmental pollution. This correction of negative externalities is often associated with pigouvian tax [14].

Pigouvian tax was introduced by British economist Arthur C Pigou. Pigou described the distinction of the marginal cost of individuals as economic agents and the social marginal cost. This framework that then becomes the internalization effort of externalities through the tax mechanism. Taxes increase the cost structure and correct the quantity of goods produced so that activities that have negative externalities will be reduced. The Pigouvian tax seeks to move the cost of damage into the perpetrator's cost structure [16].

Environmental taxes include emissions taxes, retribution on the use of natural resource and environment, and retribution on the basis of products. Emission tax is applied to the disposal of pollutants/wastes into the air, water bodies, and/or land. This tax relates to the quantity and quality of the pollutant as well as the cost of the damage. Implementation of the emissions tax will increase income, encourage pollution minimization, and technological innovation to reduce pollution [17].

\section{Method}

A descriptive method is used to describe the condition of air quality in Indonesia. Data analysis tools from Excel 2010 software is used to analyze the correlation of the population, motor vehicle, fuel consumption, air quality index ("indeks kualitas udara/IKU"), and infants" pneumonia cases in Indonesia. A descriptive method is also used to explain the opportunity of air pollution control from the transport sector using vehicle emissions tax based on literature, regulation, and prior researches.

\section{Result and Discussion}

\subsection{Air Quality in Indonesia}

In Indonesia the national ambient air quality is stated as an index, "indeks kualitas udara (IKU)". This value is based on the monitoring of $\mathrm{NO}_{2}$ to represent air pollution from the transport sector, especially gasoline-fueled vehichles and $\mathrm{SO}_{2}$ to represent air pollution from industrial sectors and diesel-fueled vehicles. IKU in the 
period 2011-2016 has a tendency to decline with the rate of decline 0.014 per year. In 2016 IKU recorded 81.61 (good) decreased quite drastically from the previous year, that is 83.84 (very good). Three provinces even have moderate, less, and very less air quality, that is Riau (72.4), Banten (58.8) and DKI Jakarta (56.4) [18].

Descriptions of population, vehicles, fuel consumption, IKU, and the cases of pneumonia in infants in Indonesia can be observed in the figure bellow.

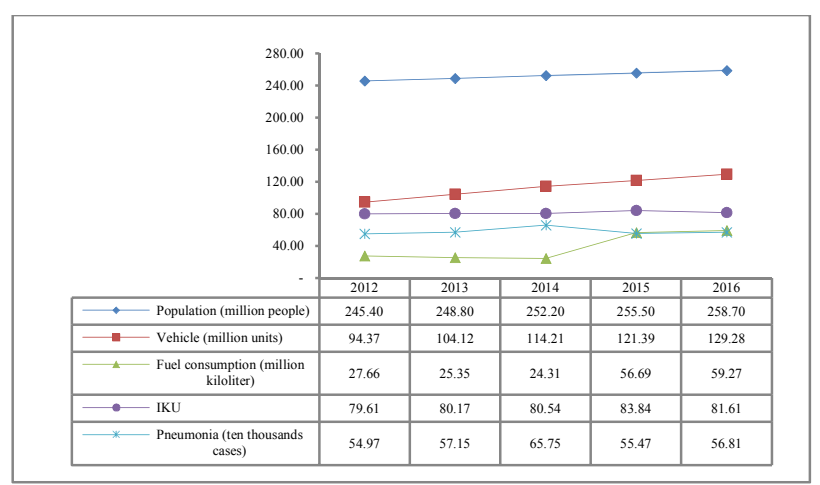

Fig. 1. Air quality index (IKU) and cases of pneumonia in infants in Indonesia with regard to population, vehicle, and fuel consumption period 2012-2016

The result of correlation analysis at the $95 \%$ confidence level of the above five variables for data of 2016 can be observed in the following tables.

Table 1. Population, vehicles, fuel consumption, IKU, and cases of infants' pneumonia in Indonesia in 2016

\begin{tabular}{|l|r|r|r|r|r|}
\hline \multicolumn{1}{|c|}{ Province } & $\begin{array}{c}\text { Population } \\
\text { (million) }\end{array}$ & $\begin{array}{c}\text { Vehichles } \\
\text { (million units) }\end{array}$ & $\begin{array}{c}\text { Fuel (million } \\
\text { liters) }\end{array}$ & IKU & $\begin{array}{c}\text { Pneumonia } \\
\text { (cases) }\end{array}$ \\
\hline Aceh & 5.10 & 3.08 & 385 & 86.3 & 1,854 \\
\hline Sumatera Utara & 14.10 & 6.38 & 3,125 & 79.2 & 7,997 \\
\hline Sumatera Barat & 5.26 & 2.32 & 964 & 82.9 & 13,868 \\
\hline Riau & 6.50 & 2.98 & 895 & 72.4 & 11,250 \\
\hline Jambi & 3.46 & 4.34 & 288 & 88.1 & 5,572 \\
\hline Sumatera Selatan & 8.16 & 5.26 & 1,397 & 81.6 & 13,505 \\
\hline Bengkulu & 1.90 & 1.10 & 188 & 85.4 & 530 \\
\hline Lampung & 8.21 & 3.15 & 513 & 77.5 & 7,684 \\
\hline Bangka Belitung & 1.40 & 1.00 & 385 & 80.4 & 7,236 \\
\hline Kepulauan Riau & 2.03 & 1.30 & 786 & 78.6 & 1,214 \\
\hline DKI Jakarta & 10.28 & 20.07 & 4,925 & 56.4 & 44,967 \\
\hline Jawa Barat & 47.38 & 10.68 & 6,159 & 78.6 & 174,612 \\
\hline Jawa Tengah & 34.02 & 15.47 & 4,192 & 77.3 & 59,650 \\
\hline DIY & 3.72 & 3.98 & 711 & 87.6 & 3,160 \\
\hline Jawa Timur & 39.08 & 15.58 & 6,070 & 83.2 & 93,279 \\
\hline Banten & 12.20 & 2.78 & 4,265 & 58.8 & 30,649 \\
\hline Bali & 4.20 & 4.56 & 1,801 & 88.3 & 6,688 \\
\hline NTB & 4.90 & 2.05 & 443 & 81.2 & 25,946 \\
\hline NTT & 5.20 & 1.30 & 312 & 82.7 & 4,176 \\
\hline Kalimantan Barat & 4.86 & 2.71 & 951 & 81.5 & 2,542 \\
\hline $\begin{array}{l}\text { Kalimantan } \\
\text { Tengah }\end{array}$ & 2.55 & 1.51 & 636 & 83.8 & 466 \\
\hline $\begin{array}{l}\text { Kalimantan } \\
\text { Selatan }\end{array}$ & 4.06 & 2.62 & 2,410 & 85.6 & 13,262 \\
\hline $\begin{array}{l}\text { Kalimantan } \\
\text { Timur }\end{array}$ & 3.50 & 2.94 & 4,796 & 80.2 & 7,153 \\
\hline Sulawesi Utara & 2.44 & 1.43 & 717 & 86.7 & 559 \\
\hline Sulawesi Tengah & 2.92 & 2.35 & 349 & 87.9 & 10,565 \\
\hline $\begin{array}{l}\text { Sulawesi Selatan, } \\
\text { Sulawesi Barat }\end{array}$ & 9.91 & 4.02 & 1,740 & 86.1 & 8,077 \\
\hline $\begin{array}{l}\text { Sulawesi } \\
\text { Tenggara }\end{array}$ & 2.55 & 1.47 & 677 & 83.5 & 3,106 \\
\hline Gorontalo & 1.15 & 0.46 & 147 & 88.3 & 4,084 \\
\hline Maluku & 1.72 & 0.64 & 364 & 87.3 & 534 \\
\hline Maluku Utara & 1.19 & 0.10 & 193 & 86.2 & 613 \\
\hline $\begin{array}{l}\text { Papua Barat, } \\
\text { Papua }\end{array}$ & 4.10 & 0.86 & 1,213 & 91.5 & 716 \\
\hline Sourrces: BPH & & & & & \\
\hline
\end{tabular}

Sources: BPH Migas, BPS, KLHK
Table 2. Correlation between population, vehicle, fuel, IKU, and cases of pneumonia in infants in Indonesia in 2016

\begin{tabular}{|l|r|r|r|r|r|}
\hline & \multicolumn{1}{|c|}{ Population } & \multicolumn{1}{l|}{ Vehichles } & \multicolumn{1}{c|}{ Fuel } & \multicolumn{1}{c|}{ IKU } & Pnumonia \\
\hline Population & 1 & & & & \\
\hline Vehichles & 0,7341105 & & & & \\
\hline Fuel & 0,7925056 & 0,7723631 & 1 & & \\
\hline IKU & $-0,258754$ & $-0,498652$ & $-0,5182843$ & & \\
\hline Pnumonia & 0,9245528 & 0,6620011 & 0,7634166 & $-0,2965140$ & \\
\hline
\end{tabular}

The result of correlation analysis shows that the population has strong correlation to the number of vehicles, fuel consumption, and the cases of infants' pneumonia; the number of vehicles has a strong correlation to fuel consumption and the cases of infants' pneumonia and has a moderate correlation to IKU; fuel consumption has a strong correlation to the cases of infants' pneumonia and moderate against IKU; IKU has a weak correlation to the cases of pneumonia.

Furthermore, the results of regression analysis at the $95 \%$ confidence level can be observed in the following tables.

Table 3. Results of regression analysis of variables (vehicles and fuel consumption) to the dependent variable (IKU) in Indonesia

\begin{tabular}{|l|r|r|r|}
\hline & Coefficients & \multicolumn{1}{|c|}{ Std Error } & \multicolumn{1}{c|}{ Stat } \\
\hline Intercept & 85,6977798 & 1,66516205 & 51,4651289 \\
\hline $\begin{array}{l}\text { Vehichles } \\
\text { (million units) }\end{array}$ & $-0,38970099$ & 0,40005491 & $-0,97411878$ \\
\hline $\begin{array}{l}\text { Fuel } \\
\text { (million liters) }\end{array}$ & $-0,0013742$ & 0,0010420 & $-1,31876887$ \\
\hline
\end{tabular}

Based on the above regression results can be seen that the value of IKU can be predicted by the formula:

$$
I K U=85.6978-0.3897 * \text { vehichles }-0.00137 * \text { fuel consumption }
$$

The above equation means that every increase of one million units of vehicles will decrease the IKU by 0.3897 and every consumption of one million liters of fuel will decrease the IKU by 0.00137 .

\subsection{The Opportunity of Air Pollution Control in Indonesia Using Vehichles Emission Tax}

Based on the condition of air quality in Indonesia as described above there is a correlation between the number of vehicles and fuel consumption to the air quality and the cases of pneumonia. Therefore, it is necessary to make efforts to control air pollution from vehichle emission. Some efforts have been made in Indonesia, such as ambient air quality monitoring, vehicle emission testing, car free day, traffic engineering, mass transportation, tree planting, green open space. These efforts are come from environmental and technical side. The economic effort has not been done yet in Indonesia. This kind of effort is an opportunity that can be taken to strengthen the environmental efforts to control air pollution from mobile sources/transportation (vehicles). One effort that can be done is by applying vehicle emissions tax as an environmental economic instrument. 


\subsubsection{Legal Regulation in Indonesia}

There are several legal regulations in Indonesia that can be the basis of the effort to control air pollution using environmental economic instruments in the form of environmental taxes.

Law Number 32 Year 2009 "The Protection and Management of The Environment" Article 2 letter $j$ contains the polluter pays principle. Article 43 paragraph (3) states that the environmental tax is one of the environmental economic instruments in the form of incentives and/or disincentives for polluters.

Government Regulation Number 46 Year 2017 "Environmental Economics Instrument" states in Article 1 that environmental economic instruments are a set of economic policies to encourage central government, local government, or each person toward environmental preservation. One of them is an instrument of economic and development planning which can be realized by the internalization of environmental cost which is carried out by including the cost of pollution and /or environmental damage in calculation of production cost or cost of a business and/or activity (Article 3, Article 4, Article 18).

Law Number 28 Year 2009 "Regional Tax and Regional Retribution" states in Article 5 that the basis of the implementation of vehicle tax is the selling value of motor vehicles and the weight reflecting the relative level of road damage and/or environmental pollution caused by the use of vehicles.

\subsubsection{Prior Researches about Environmental Tax}

Several studies related to environmental taxes have been published. In 2016 Filippini and Heimsch conducted "The Regional Impact of a $\mathrm{CO}_{2}$ Tax on Gasoline Demand: A Spatial Econometric Approach" [19]. This study aims to estimate the price elasticity and earnings on gasoline demand by considering spatial effects as well as analyzing the spatial effects of $\mathrm{CO}_{2}$ tax policy implementation on the pattern of gasoline consumption in Switzerland. The results show that a $10 \%$ increase in gasoline consumption in a municipality will spread to other cities and lead to an increase in gasoline consumption by $4.2 \%$. The application of taxes could reduce gasoline consumption by \pm 510 million liters and reduce $\mathrm{CO}_{2}$ emissions by about 1.2 million tonnes. Implementation of $\mathrm{CO}_{2}$ tax in the long term can affect the pattern of gasoline consumption and reduce $9 \%$ of greenhouse gas emissions in Switzerland.

As in Indonesia has been conducted researches on vehicle tax estimation by Bestari, et al. in 2014 and Hidayat, et al in 2016. Estimated tax rate of diesel-fueled public transport vehicles in DKI Jakarta that internalize economic losses based on health costs is Rp.4,617,119/vehicle/year. Key players in the formulation and implementation of this tax policies are environmental agencies, transportation agencies and universities/academic [7]. The estimated tax value of each gasoline-fueled public transport in Bogor City that internalizes economic losses based on health costs is Rp.178,397/vehicle/year [20].

\subsection{Data Required to Estimate Vehicle Emission Tax}

One of the way to estimate vehicle emissions tax is by internalizing the economic losses due to air pollution for public health. The data required are primary and secondary data. Primary data can be obtained from the respondents through interviews and filling out the questionnaires related to the using of motor vehicles, illness suffered, and the costs incurred for treatment and care as well as loss of income during illness. Secondary data can be obtained from related institution, literature, and legal regulation, ie data of population, vehicles, disease case, fuel selling, air quality, and vehicle pollution load [7][20].

\subsection{Method Used}

One of the method that can be used to estimate vehicle emission tax which internalize economic loss caused by pollution for health is cost of illness method. Regulation of the Minister of Environment Number 7 of 2014 "Environmental Loss due to Pollution" states that the cost of illness approach is used if pollution and/or environmental damage cause health problems so that the patient can not work. Losses can be calculated as long as the person is ill. Costs that are calculated, include the cost of medical care, medical consultation fee, medicine and laboratory; consumption expenses during illness; accommodation expenses when ill; transportation expenses during treatment; loss of income; declining productivity. Furthermore, the tax value every pollutant is estimated by dividing the total economic loss with total pollution load [7] [20].

\section{Conclusion}

Air quality in Indonesia based on IKU is still in good condition. However, there are provinces with moderate IKU values, even very less. The number of vehicles and fuel consumption correlate to the value of IKU and can decrease its value. Therefore it is necessary to control air pollution from the source (motor vehicle). One effort that can strenghten the efforts that have been done so far in controlling air pollution is implement the environmental economic instruments. Legal regulations in Indonesia have accommodated the environmental economic instruments that can be implemented in the form of environmental taxes to maintain environmental sustainability. This is an opportunity to control air pollution. The prior research show that emissions tax can reduce fuel consumption and reduce greenhouse gas emissions. So that it can support the low carbon development. The emission tax can be calculated by internalizing the economic losses due to air pollution for public health. 


\section{Suggestion}

Air pollution that become problem in almost every big city in Indonesia and have impact to public health is expected to be solved one of them by applying emission tax of motor vehicle. Therefore, research related to motor vehicle taxation estimates that internalize the economic losses of air pollution for public health needs to be done especially for private vehicles and motorcycles that have not been done yet. The hope, the results of the estimated value of vehicle emissions tax can be used in policymaking to control air pollution from the transportation sector.

\section{Refference}

1. Badan Pusat Statistik, Statistik Indonesia 2018. Jakarta: Badan Pusat Statistik, (2018).

2. Badan Pusat Statistik, Statistik Indonesia 2014. Jakarta, (2014).

3. Badan Pusat Statistik, Statistik Transportasi Darat 2015. Jakarta: Badan Pusat Statistik, (2016).

4. G. R. Bivina, V. Landge, and V. S. S. Kumar, "Socio Economic Valuation of Traffic Delays," Transp. Res. Procedia, vol. 17, pp. 513-520, (2016).

5. E. Buwana, H. S. Hasibuan, and C. Abdini, "Alternatives Selection for Sustainable Transportation System in Kasongan City," Procedia - Soc. Behav. Sci., vol. 227, pp. 11-18, (2016).

6. Republik Indonesia, Peraturan Pemerintah Nomor 46 Tahun 2017 tentang Instrumen Ekonomi Lingkungan Hidup. Republik Indonesia, (2017), pp. 1-54.

7. L. R. Bestari, A. Hidayat, and M. Yani, "Estimasi Nilai Pajak Kendaraan Solar Terkait Kerugian Pencemaran Udara (Studi Kasus: Metro Mini di DKI Jakarta)," J. Ekon. Pertanian, Sumberd. dan Lingkung., vol. 2, pp. 98-111, (2014).

8. A. Tarigan, "Estimasi Emisi Kendaraan Bermotor di Beberapa Ruas Jalan Kota Medan," Universitas Sumatera Utara, (2009).

9. M. Soedomo, Kumpulan Karya Ilmiah Mengenai
Pencemaran Udara. Bandung: Penerbit ITB, (2001).

10. I. W. Purwanto, C.P., Arthana, I.W., Suarna, "Inventarisasi Emisi Sumber Bergerak di Jalan (On Road) Kota Denpasar," Ecotrophic:, vol. 9, no. 1, pp. 1-9, (2015).

11. Bappenas, "Mewujudkan Pertumbuhan Ekonomi Hijau untuk Indonesia yang Sejahtera," Jakarta, (2015).

12. D. Owen and Anthony, "Environmental Externalities Market Distortions and The Economics of Renewable Energy Technologies," Energy J., vol. 25, no. 3, (2004).

13. G. Santos, H. Behrendt, L. Maconi, T. Shirvani, and A. Teytelboym, "Externalities and Economic Policies in Road Transport," Res. Transp. Econ., vol. 28, no. 1, pp. 2-45, (2010).

14. A. Fauzi, Valuasi Ekonomi dan Penilaian Kerusakan Sumber Daya Alam dan Lingkungan. Bogor: IPB, (2014).

15. Kementerian Negara Lingkungan Hidup, Panduan Valuasi Ekonomi Sumber Daya Alam dan Lingkungan Hidup. Jakarta, (2007).

16. Kristiaji, "Bridge Between Tax and Economics," Insid. Tax, vol. 44, (2014).

17. D. Popp, "International Innovation and Diffusion of Air Pollution Control Technologies: The Effects of NOx and SOx Regulation in The US, Japan and Germany," J. Environ. Econ. Manage,, vol. 51, no. July, pp. 46-71, (2006).

18. Kementerian Lingkungan Hidup dan Kehutanan, Indeks Kualitas Lingkungan Hidup Indonesia 2016. Jakarta, (2016).

19. M. Filippini and F. Heimsch, "The Regional Impact of A CO2 Tax on Gasoline Demand: A Spatial Econometric Approach," Resour. Energy Econ., (2016).

20. A. Hidayat and S. D. Syafitri, "Estimasi nilai pajak emisi dan kebijakan kendaraan umum berbahan bakar bensin di kota bogor," Risal. Kebijak. Pertan. dan Lingkung., vol. 3, no. 1, pp. 1-10, (2016). 